\title{
Hypoglycemic and antioxidative activities of ethanol seed extract of Hunteria umbellate (Hallier F.) on streptozotocin- induced diabetic rats
}

Olubanke O. Ogunlana ${ }^{1 *}$, Babatunde O. Adetuyi ${ }^{2^{*}}$, Miracle Rotimi ${ }^{1}$, lohor Esalomi ${ }^{1}$, Alaba Adeyemi ${ }^{1}$, Julie Akinyele ${ }^{1}$, Oluseyi E. Ogunlana ${ }^{1}$, Oluwatosin A. Adetuyi $i^{3}$, Oluwaseun A. Adebisi ${ }^{3}$, Edward K. Opata², Roua S. Baty ${ }^{4}$ and Gaber El-Saber Batiha ${ }^{5}$

\begin{abstract}
Background: Diabetes, a global cause of mortality in developing countries is a chronic disorder affecting the metabolism of macromolecules and has been attributed to the defective production and action of insulin characterized by persistent hyperglycemic properties. This global disorder harms organs of the body such as the liver, kidney and spleen. Medicinal plants such as Hunteria umbellate have been shown to possess hypoglycemic, antioxidative and anti-diabetic properties owing to the high concentration of active phytochemical constituents like flavonoids and alkaloids.

The present study seeks to evaluate the hypoglycemic activities of ethanolic seed extract of Hunteria umbellate on streptozotocin-induced diabetes rats.

Methods: Thirty (30) female experimental rats were randomly divided into five groups with six rats per group and were administered streptozotocin (STZ) and Hunteria umbellate as follows. Group 1 served as control and was given only distilled water, group 2 rats were administered $60 \mathrm{mg} / \mathrm{kg} \mathrm{STZ;} \mathrm{Group} 3$ was administered $60 \mathrm{mg} / \mathrm{kg} \mathrm{STZ}$ and $100 \mathrm{mg} / \mathrm{kg}$ metformin; group 4 rats were administered $60 \mathrm{mg} / \mathrm{kg} \mathrm{STZ}$ and $800 \mathrm{mg} / \mathrm{kg}$ Hunteria umbellate, group 5 rats $60 \mathrm{mg} / \mathrm{kg} \mathrm{STZ}$ and $400 \mathrm{mg} / \mathrm{kg}$ Hunteria umbellate. The fasting blood glucose level of each rat was measured before sacrifice. Rats were then sacrificed $24 \mathrm{~h}$ after the last dose of treatment.

Results: The results showed that Hunteria umbellate significantly reversed STZ-induced increase in fasting blood glucose and increase in body and organs weight of rats. Hunteria umbellate significantly reversed STZ-induced decrease in antioxidant enzyme in liver, kidney and spleen of rats. Hunteria umbellate significantly reversed STZinduced increase in oxidative stress markers in liver, kidney and spleen of rats.
\end{abstract}

\footnotetext{
* Correspondence: banke.ogunlana@covenantuniversity.edu.ng;

badetuyi@pcu.edu.ng

'Department of Biological Sciences (Biochemistry Unit, Covenant University,

Ogun State, Ota, Nigeria

${ }^{2}$ Department of Natural Sciences (Biochemistry unit), Faculty of Pure and

Applied Sciences, Precious Cornerstone University, Ibadan, Oyo State, Nigeria

Full list of author information is available at the end of the article
}

\section{Springer Open}

(c) The Author(s). 2021 Open Access This article is licensed under a Creative Commons Attribution 4.0 International License, which permits use, sharing, adaptation, distribution and reproduction in any medium or format, as long as you give appropriate credit to the original author(s) and the source, provide a link to the Creative Commons licence, and indicate if changes were made. The images or other third party material in this article are included in the article's Creative Commons licence, unless indicated otherwise in a credit line to the material. If material is not included in the article's Creative Commons licence and your intended use is not permitted by statutory regulation or exceeds the permitted use, you will need to obtain permission directly from the copyright holder. To view a copy of this licence, visit http://creativecommons.org/licenses/by/4.0/. 
Conclusion: Collectively, our results provide convincing information that inhibition of oxidative stress and regulation of blood glucose level are major mechanisms through which Hunteria umbellate protects against streptozotocin-induced diabketes rats.

Keywords: Diabetes, Hunteria umbellate, Streptozotocin, hypoglycemic, Fasting blood glucose

\section{Background}

According to the International Diabetes Federation (IDF), approximately 13.6 million people in Africa have diabetes. Sub-saharan Africa is estimated to have a diabetes incidence burden of over 7 million people this estimate is expected to double and exceed 15 million by 2025. The prevalence of diabetes varies by region based on the level of development and civilization, especially in Africa. In the rural or less developed areas the prevalence is about $1 \%$ which sharply contrast with about $7 \%$ prevalence in developing areas and about $8-13 \%$ in more developed areas in sub-Saharan Africa [1].

Perhaps, one of the oldest disorders known to humanity is diabetes mellitus. It is a chronic metabolic disorder emanating either from insulin deficiency (Insulin inadequacy brings about Type 1 Diabetes Mellitus - T1DM) or insensitivity of insulin (Type 2 Diabetes Mellitus T2DM). T2DM arises from a couple of factors and may arise as a synergy between hereditary, ecological and social risk factors. It is often associated with features such as hyperglycemia, insulin resistance and deficiency of insulin [5].

Normally, individuals with diabetes have a risk of developing a progressive illness, for example, visual impairment, renal infection, coronary disease, cerebrovascular and peripheral vascular diseases [2]. T2DM, if uncontrolled and unmanaged, may result into short and long term complexities which are perhaps lethal. There are various complications related to T2DM which evolves around diabetic nephropathy [3], diabetic neuropathy [4], diabetic retinopathy [5], diabetic ketoacidosis [6], stroke, liver injury [7], fatty liver disease and a lot more.

Elevated liver enzymes, fatty liver disease, cirrhosis, hepatocellular carcinoma and acute liver failure are examples of liver associated disorders found in diabetes [8]. Chronically elevated insulin level, as well as relative insulin resistance, cause a cascade of reactions that lead to an increase in lipogenesis and associated fatty changes. Excess amount of free fatty acid is known to be hepatotoxic leading to disruption of the cell membrane, mitochondrial dysfunction, oxidative damage and increase in proinflammatory cytokine - tissue Necrotic Factor [7].

The kidney on the other hand is an extremely complex organ with versatile functions in the body, including, but not limited to, removal of waste, ion and water balance, blood pressure maintenance, regulation of glucose level and erythropoietin generation or vitamin $\mathrm{D}$ activation
[9]. Under diabetic conditions, many of these processes are disturbed via a combination of hemodynamic and metabolic changes; hyperglycemia also activates a series of changes leading to glomerular and tubular dysfunction accelerating glomerular cell death [9].

Diabetes significantly diminishes immune response capacity, it causes a suppression of immune cell function, reduction in the size of organs of the immune system such as the spleen [10]. Hossam et al. (2015) reported the detrimental pathological effects of diabetes on an important organ of the immune system which is the spleen and the treatment effect of phytochemicals [10].

It has been reported that over $64 \%$ of the world population depends on medicinal plants for their primary health care [11]. Across Africa, there is little or no access to modern medicine and a lot of citizens depend on indigenous medicine or health care [12]. With this increase in the incidence of diabetic patients in the world, there is also a need to discover and validate the effectiveness of more therapeutic agents in the management of diabetes mellitus.

Herbs, spices and indigenous plants have been utilized for treating diabetes in Egypt, India and China for many years. Such plants include onion, garlic, neem, etc. Onion has a hypoglycemic impact in fasting depancreatized rats. Therapeutic plants are modest, effectively accessible and have no deleterious effects, and accordingly may be considered as another option in treating diabetes.

The extracts from various parts of Hunteria umbellata are of great value in the local management of various ailments and diseases. Among the Yoruba herbalists, powdered dry seeds of Hunteria umbellata are presumed for the treatment of fever, torment, stomach colic and inconveniences, diabetes mellitus and obesity. In diabetes mellitus local treatment, a normal of 2-3 teaspoonful's (10$15 \mathrm{~g}$ ) of powdered dry seed immersed a glass of high temp water for $20-30 \mathrm{~min}$ is prescribed for a grown-up to be taken orally every day [13]. Extracts from Hunteria umbellata have been shown to have antidiabetic, antioxidative and erection stimulating properties [14-16]. It also has aphrodiac properties via the modualtion of arginase and nitric oxide activities [17], Its alkaloid fraction has been shown be cardioprotective and hyperlipidemic [18].

This study aims to evaluate the hypoglycemic activities of the ethanolic seed extract of Hunteria umbellata and its effect on the oxidative markers in organs of albino rats induced with streptozotocin-induced diabetes. 


\section{Materials and methods}

\section{Chemicals and reagents}

Streptozotocin (STZ), Glucose-D, potassium dihydrogen phosphate $\left(\mathrm{KH}_{2} \mathrm{PO}_{4}\right)$, dipotassium hydrogen phosphate $\left(\mathrm{K}_{2} \mathrm{HPO}_{4}\right), 10 \%$ Trichloroacetic acid (TCA), Ellman's reagent, 5, 5-dithiobisnitro benzoic acid (DTNB), sodium nitrate, Glutathione powder, 1-chloro-2,4-dinitrobenzene (CDNB), Ethanol, hydrogen peroxide were all obtained from SIGMA, USA and Clous clone Int'l Wuhan, China.

\section{Plant collection}

Seeds of Hunteria umbellata plant were collected from Ota market, Ogun State, Nigeria in August 2020. Botanical identification and authentication were done by Dr Popoola, Covenant University, Ota, Ogun State, Nigeria. The seeds were completely dried under room temperature for 4 weeks protected from direct heat or sunlight. After drying, the seeds were de-coated from their light brown thin coatings.

\section{Plant extraction}

Upon collected and identification of Hunteria umbellata seeds, $215 \mathrm{~g}$ of the dry seeds were weighed and then grounded to a white-to-light brown fine powder using a domestic blender. Consequent upon grinding of the seeds, $206 \mathrm{~g}$ of the finely powdered sample was soaked in $1833 \mathrm{ml}$ of ethanol and made to total volume. It was left to stand for $72 \mathrm{~h}$ in an air-tight container and stirred at intervals. After $72 \mathrm{~h}$, the mixture was vigorously shaken and filtered using a piece of clean muslin cloth. The filtrate was kept in an air-tight container. The residue was re-soaked in ethanol and left to stand for another $72 \mathrm{~h}$ with stirring at intervals. The mixture was filtered and the filtrate was added to the first and the crude extract was obtained using the rotary evaporator with a percentage yield of $89 \%$.

\section{Experimental animals}

Thirty (30) female white albino Wistar rats (4-8 weeks old), weighing 150-200 g were obtained in the central animal house, Covenant University, Ota. Upon collection, all animals were fed a standard feed and water ad libitum initially for two weeks for acclimatization before the commencement of any form of any treatment. Ethics protocols as laid down by the animal ethics committee of the Department of Biological Sciences, Covenant University, Ota, Ogun State, Nigeria (PCU/ACUREC/018).

\section{Diabetes induction}

Following an overnight fast and except for animals in the negative control group, all animals were given a single intraperitoneal injection of $60 \mathrm{mg} / \mathrm{kg}$ STZ freshly dissolved in citrate buffer $\mathrm{pH} 4.5$ targeted at inducing diabetes. A status of hyperglycaemia was ascertained $72 \mathrm{~h}$ after the injection by estimating the blood glucose level with an Accu-check sensor comfort glucometer. Only the rats with fasting blood glucose levels $\geq 250 \mathrm{mg} /$ dl were considered diabetic.

\section{Experimental design}

Diabetic rats were weighed and distributed into 5 groups each consisting of 6 rats as shown in the table below (Table 1).

The animals were dosed according to their body weight. The fasting blood glucose of each animal was also checked by measuring the tail vein blood glucose level with an Accu-check sensor comfort glucometer.

\section{Oral Glucose Tolerance Test (OGTT)}

Two types of Oral glucose tolerance test were performed: Diabetic OGTT (on diabetic animals) and Normoretic Oral glucose tolerance test (on non-diabetic animals).

The animals fasted for $12 \mathrm{~h}$ before the day of OGTT. The fasting glycaemia was measured and defined as zero-time. After this procedure, the animals received their treatment orally and after $30 \mathrm{~min}$ all the groups received an oral load of glucose $(2.0 \mathrm{~kg} / \mathrm{bw})$. The blood glucose levels were then measured 30, 60, 120 and 150 min after administration of glucose as shown in Tables 2 and 3.

\section{Reduced glutathione determination}

Reduced glutathione on reaction with DTNB (5,5'dithiobis nitro benzoic acid) forms a lightly coloured product that absorbs light maximally at about $412 \mathrm{~nm}$. The reduced glutathione (GSH) content of liver tissue as non-protein sulphydryls was estimated according to the method described by Sedlak and Lindsay, [19].

Table 1 Experimental design describing the groupings and dosage

\begin{tabular}{|c|c|c|c|}
\hline GROUP & LABEL & DOSAGE & No OF ANIMALS \\
\hline 1. & Normal control & Distilled water & 6 \\
\hline 2. & Positive control & $60 \mathrm{mg} / \mathrm{kg} \mathrm{STZ}$ & 6 \\
\hline 3. & Positive control & 60 mg/kg STZ + Metformin (100 mg/kg) & 6 \\
\hline 4. & Plant extract & 60 mg/kg STZ + H. umbellata (400 mg/kg) & 6 \\
\hline 5. & Plant extract & 60 mg/kg STZ + H. umbellata (800 mg/kg) & 6 \\
\hline
\end{tabular}


Table 2 Effect of $H$. umbellata on oral glucose tolerance test in diabetic rats

\begin{tabular}{|c|c|c|c|c|c|}
\hline GROUPS & Zero time & $30 \mathrm{~min}$ & $60 \mathrm{~min}$ & $120 \mathrm{~min}$ & $150 \mathrm{~min}$ \\
\hline CONTROL & $82.83 \pm 6.60^{b}$ & $151.83 \pm 28.20^{b}$ & $157.16 \pm 12.05^{b}$ & $116.16 \pm 7.52^{b}$ & $89.33 \pm 6.40^{b}$ \\
\hline 60 mg/kg STZ & $421.00 \pm 42.43^{* a}$ & $495.40 \pm 64.06^{* a}$ & $466.00 \pm 76.24^{* a}$ & $423.40 \pm 85.60^{* a}$ & $362.40 \pm 78.97^{* a}$ \\
\hline 60 mg/kg STZ + METFORMIN & $188.20 \pm 64.38^{\mathrm{b}}$ & $159.20 \pm 45.35^{b}$ & $94.60 \pm 26.78^{b}$ & $74.60 \pm 12.96^{b}$ & $70.80 \pm 11.55^{b}$ \\
\hline 60 mg/kg STZ + H.U. 400 mg & $368.33 \pm 95.86^{*}$ & $450.33 \pm 74.43^{* a}$ & $393.00 \pm 80.10^{* a}$ & $330.00 \pm 66.05^{* a}$ & $247.16 \pm 74.13^{* a}$ \\
\hline 60 mg/kg STZ + H.U. 800 mg & $230.66 \pm 90.93$ & $474.00 \pm 35.23^{* a}$ & $450.66 \pm 52.34^{* a}$ & $408.66 \pm 51.77^{* a}$ & $353.00 \pm 67.81^{* a}$ \\
\hline
\end{tabular}

Superscripts ${ }^{*} \mathrm{ab}$ represent values that are significantly $(\mathrm{p}<0.05)$ different from negative control, metformin treated group and positive control respectively

\section{Glutathione- S- transferase activity determination}

Glutathione $-\mathrm{S}$ - transferase an enzyme that utilizes glutathione as a cofactor in its antioxidative activity was determined by the method according to Habig et al., [20]. This enzyme demonstrates a relatively high activity with 1-Chloro - 2,4-dinitrobenzene (CDNB) as the second substrate. Consequently, the conventional assay for glutathione-s-transferase activity utilizes 1-Chloro-2,4dinitrobenzene as substrate. When this substrate is conjugated with reduced glutathione (GSH), its absorption maximum shifts to a longer wavelength. The absorption increase at the new wavelength of $340 \mathrm{~nm}$ which provides a direct measurement of the enzymatic reaction.

\section{Catalase activity determination}

The UV absorption of hydrogen peroxide can be measured at $240 \mathrm{~nm}$, whose absorbance decreases when degraded by the enzyme catalase. From the decrease in absorbance, enzyme activity can be calculated. Serum catalase activity was determined according to the method of Beers and Sizer as described by Usoh et al., [21].

\section{Lipid peroxidation}

Thiobarbituric acid reactive substances is an index of lipid peroxidation. This was determined by measuring thiobarbituric acid reactive substances (TBARS) present the homogenate using the method of Beuge and Aust, [22].

\section{Peroxidase determination}

In the presence of the hydrogen donor pyrogallol, peroxidase converts hydrogen peroxide to water and oxygen. The oxidation of pyrogallol to a coloured product called purpurogallin can be followed spectrophotometrically at430nm. The method proposed by Reddy et al. [23] was adopted for assaying the activity of peroxidase.

\section{Statistical analysis}

All data are expressed as mean and Standard Error of Means (S.E.M.). One-way analysis of variance (ANOVA) was performed using GraphPad prism 6.0. Multiple comparison was done using Tukey's multiple comparison test $(\mathrm{p}<0.05)$.

\section{Results}

Fasting blood glucose levels of experimental animals were significantly reduced when compared to negative control as shown in Table $4(\mathrm{p}<0.05)$.

Metformin, H.U $800 \mathrm{mg}$ and H.U $400 \mathrm{mg}$ are groups treated with $100 \mathrm{mg} / \mathrm{kg}$ metformin, $800 \mathrm{mg} / \mathrm{kg} H$. umbellata and $400 \mathrm{mg} / \mathrm{kg} \mathrm{H}$. umbellata respectively. The positive and negative controls are untreated diabetic and untreated non-diabetic groups respectively.

Metformin, H.U $800 \mathrm{mg}$ and H.U $400 \mathrm{mg}$ are groups treated with $100 \mathrm{mg} / \mathrm{kg}$ metformin, $800 \mathrm{mg} / \mathrm{kg} H$. umbellata and $400 \mathrm{mg} / \mathrm{kg} \mathrm{H}$. umbellata respectively. The negative and normal controls are untreated diabetic and untreated non-diabetic groups respectively.

Metformin, $H$. umbellata $800 \mathrm{mg}$ and $H$. umbellata $400 \mathrm{mg}$ are groups treated with $100 \mathrm{mg} / \mathrm{kg}$ metformin, $800 \mathrm{mg} / \mathrm{kg} \mathrm{H}$. umbellata and $400 \mathrm{mg} / \mathrm{kg}$ H. umbellata respectively. The positive and negative controls are untreated diabetic and untreated non-diabetic groups respectively.

Metformin, $H$. umbellata $800 \mathrm{mg}$ and $H$. umbellata $400 \mathrm{mg}$ are groups treated with $100 \mathrm{mg} / \mathrm{kg}$ metformin, $800 \mathrm{mg} / \mathrm{kg} \mathrm{H}$. umbellata and $400 \mathrm{mg} / \mathrm{kg} \mathrm{H}$. umbellata respectively. The positive and negative controls are untreated diabetic and untreated non-diabetic groups respectively.

We observed that in the liver of STZ induced diabetic rats, there was a significant decline in glutathione, glutathione-S- transferase, and peroxidase levels when

Table 3 Effect of $H$. umbellata on oral glucose tolerance test in non-diabetic rats

\begin{tabular}{lllcc}
\hline GROUPS & ZERO & $\mathbf{3 0}$ min & $\mathbf{6 0}$ min & $\mathbf{1 2 0}$ min \\
\hline 60 mg/kg STZ + METFORMIN & $75.33 \pm 2.96$ & $105.67 \pm 25.67$ & $95.33 \pm 12.33^{*}$ & $64.00 \pm 8.14^{*}$ \\
60 mg/kg STZ+ H.U & $102.00 \pm 4.16^{* a}$ & $131.00 \pm 20.93$ & $110.67 \pm 10.87^{*}$ & $86.67 \pm 7.83^{*}$ \\
NORMAL CONTROL & $82.83 \pm 6.61$ & $151.83 \pm 28.20$ & $157.11 \pm 12.05$ & $116.17 \pm 7.52$ \\
\hline
\end{tabular}

Superscripts ${ }^{*} \mathrm{ab}$ represent values that are significantly $(\mathrm{p}<0.05)$ different from negative control, metformin treated group and positive control respectively 
Table 4 Percentage reduction in fasting blood glucose levels

\begin{tabular}{lc}
\hline GROUPS & \% REDUCTION \\
\hline NORMAL CONTROL & 7.96 \\
$60 \mathrm{mg} / \mathrm{kg} \mathrm{STZ}$ & 15.79 \\
$60 \mathrm{mg} / \mathrm{kg} \mathrm{STZ}+$ METFORMIN & $81.73^{*}$ \\
$60 \mathrm{mg} / \mathrm{kg} \mathrm{STZ}+$ H.U. $400 \mathrm{mg}$ & $79.18^{*}$ \\
$60 \mathrm{mg} / \mathrm{kg} \mathrm{STZ}+$ H.U. $800 \mathrm{mg}$ & $82.44^{*}$
\end{tabular}

Superscripts ${ }^{*}$ a b represents values that are significantly different from negative control, metformin group and positive control respectively $(p<0.05)$

compared to the negative control. However, treament with metformin and graded doses of H.umbellata led to significant amelioration when compared to STZ- only treatment group as shown in Fig. 1. Also, adminstration of STZ lead to significant elevation in lipid peroxidation as compared negative control group. Interestingly, meformin and graded doeses of H.umbellata lead to significant amelioration when compared to STZ-only treatment group.

Results from this study shows that in the kidney of STZ induced diabetic rats, there was a significant decline in glutathione, glutathione-S- transferase, and peroxidase levels when compared to the negative control. However, treament with metformin and graded doses of H.umbellata led to significant amelioration when compared to STZ- only treatment group as shown in Fig. 2. Also, adminstration of STZ lead to significant elevation in lipid peroxidation as compared negative control group. Interestingly, meformin and graded doeses of H.umbellata lead to significant amelioration when compared to STZ-only treatment group.

Results from this study shows that in the spleen of STZ induced diabetic rats, there was a significant decline in glutathione, glutathione-S- transferase, and peroxidase levels when compared to the negative control. However, treament with metformin and graded doses of H.umbellata led to significant amelioration when compared to STZ-only treatment group as shown in Fig. 3. Also, adminstration of STZ lead to significant elevation in lipid peroxidation as compared negative control group. Interestingly, meformin and graded doeses of H.umbellata lead to significant amelioration when compared to STZ-only treatment group.

\section{Discussion}

Glucose homeostasis is constrained by endocrine pancreatic cells, and any pancreatic unsettling influence can bring about diabetes. Hyperglycemia enhances the production of reactive oxygen species, leading to oxidative stress which is involved in the damage and failure of different organs such as the kidney, spleen and liver. To combat the damage induced by the chronic hyperglycemia associated with diabetes, studies have shown that therapeutic plants with high quantities of flavonoids and alkaloids usually possess hypoglycemic and antidiabetic effects. One of such therapeutic plants is the H. umbellate. This study, therefore, examined the protective effect of ethanol extract of $H$. umbellate against hyperglycemia associated with diabetes induced by streptozotocin.

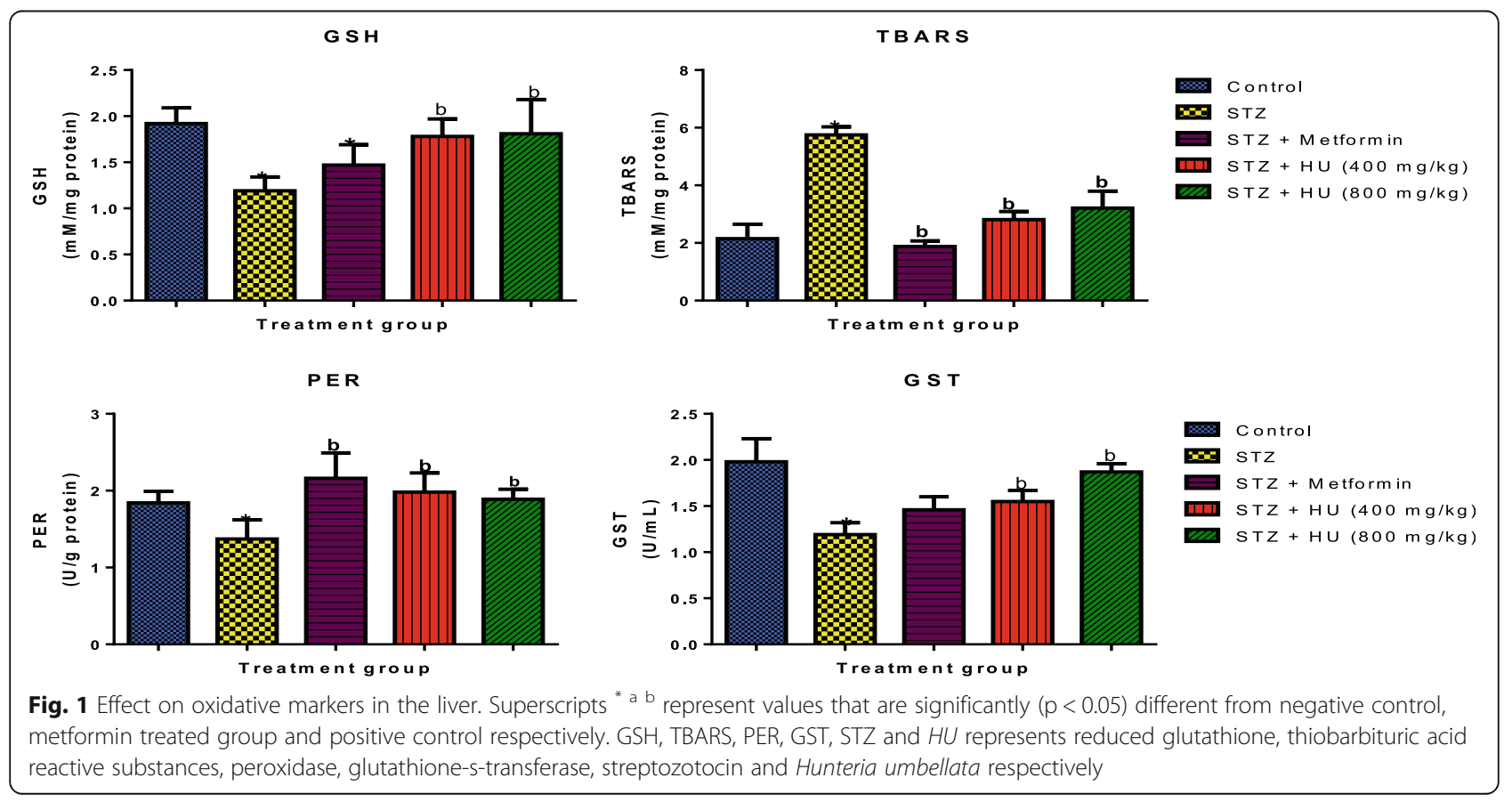




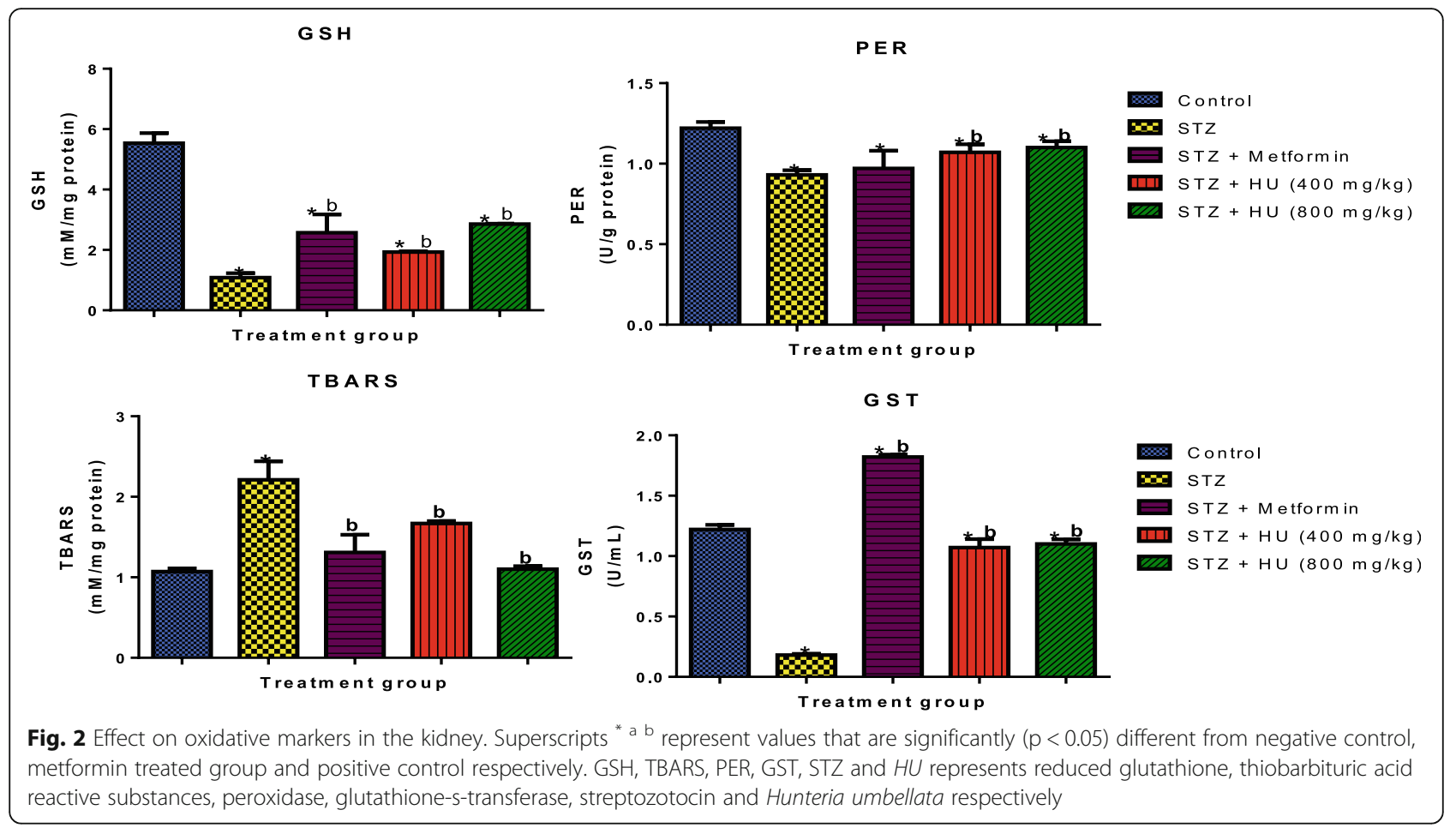

The continuous administration of streptozotocin for 3 weeks brought about critical diminishing of blood glucose levels in the negative control group, in the cotreated group, the blood glucose level was restored when compared with the untreated diabetic rats (Table 4). The most potent hyperglycemic power of $H$. umbellata dependent on improving FBG levels was observed at a dose of $800 \mathrm{mg} / \mathrm{kg}$ which was similar to metformin

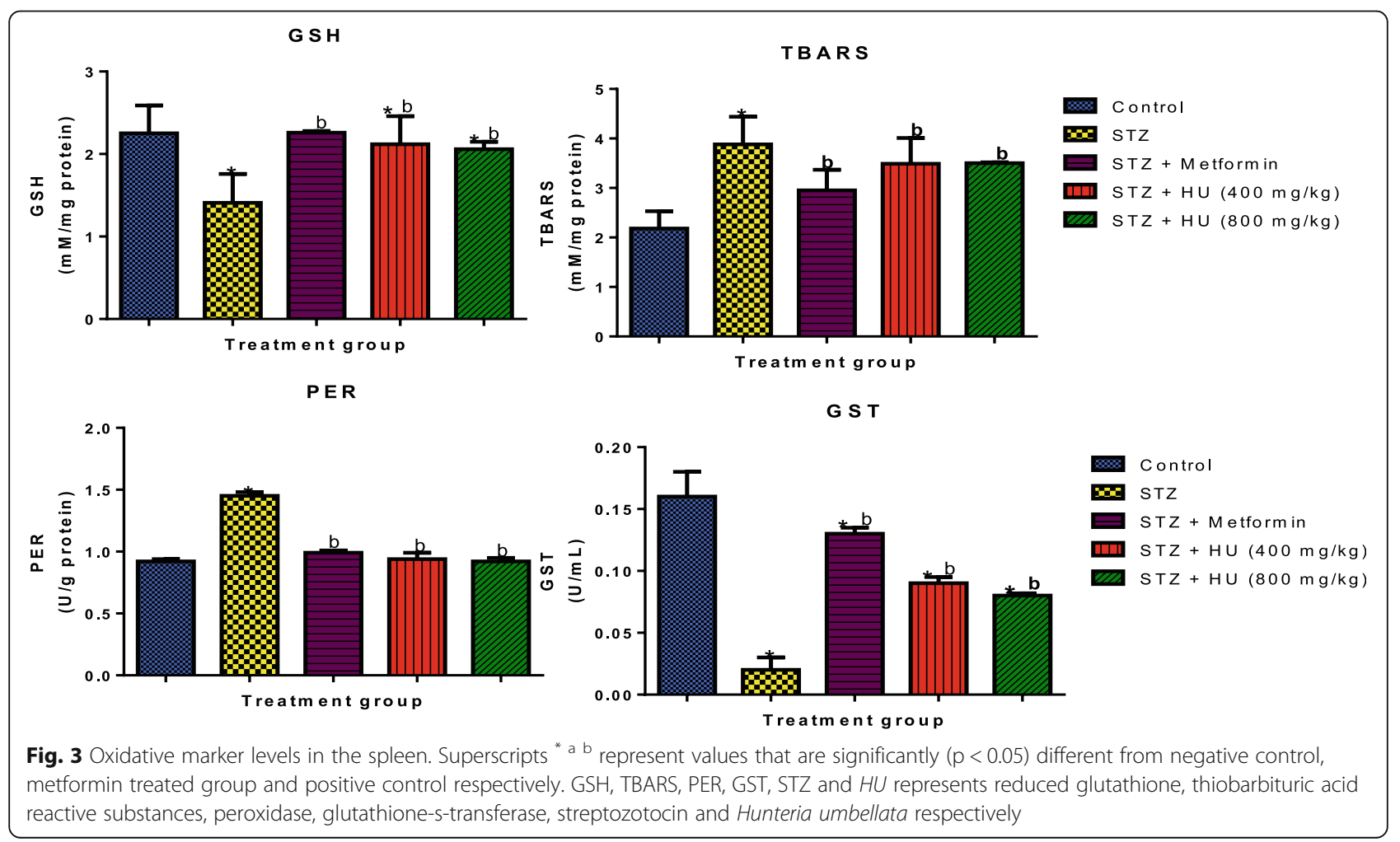




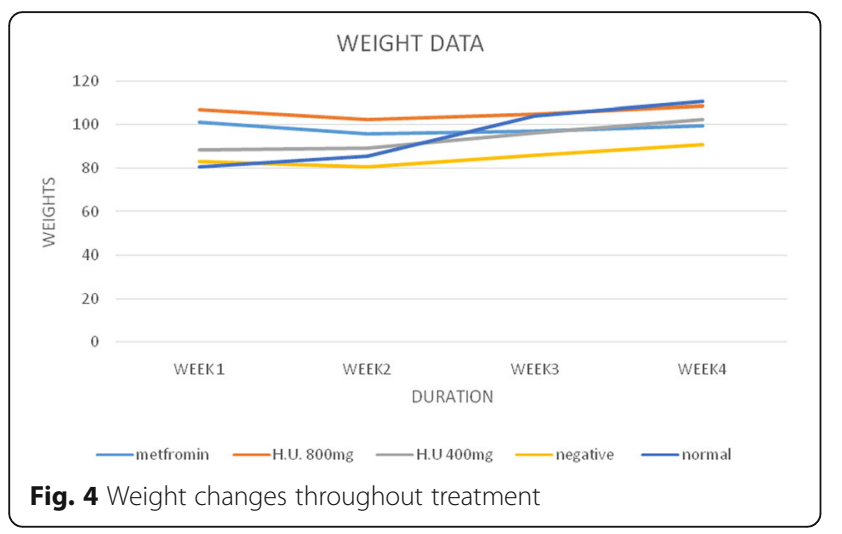

(standard medication). The glucose reducing impacts of $H$. umbellata could be attributed to the presence of a high amount of flavonoids, terpenes, cardiovascular glycosides, saponins, etc. [24].

Streptozotocin-induced diabetes is characterized by extreme loss of body weight. This decrease in weight might be brought about by catabolic responses prompting degradation of primary proteins because of diabetes. Primary proteins are known to add to body weight. In this study, following STZ administration, the blood glucose levels of rats significantly increased; this is accompanied by huge diminishing body weight. Be that as it may, treatment with $H$. umbellata concentrate and metformin restored the bodyweight step by step (Fig. 4). The weight gains in diabetic rats is possibly because of the capacity of the treatments to diminish hyperglycaemia [25]. This is in accordance with the report from Longe and Momoh, [24] that treatment with methanolic extract of $H$. umbellata appreciably increased the weight of diabetic animals after 14 days.

Contrary to the overall decrease in body weight observed in STZ- induced diabetic rats, a significant increase in the relative weights of the liver and kidney were observed in comparison to the normal rats and significant decreases in the weight of the spleen compared to the normal control (Table 5). This could be an index of organ impairment [26].

Oral glucose tolerance test gauges the capacity of the body to use the main source of energy which is glucose.

Table 5 Relative organ weight

\begin{tabular}{llll}
\hline GROUPS & LIVER & KIDNEY & SPLEEN \\
\hline NORMAL CONTROL & $3.53 \pm 0.09^{\mathrm{a}}$ & $0.72 \pm 0.04^{\mathrm{ab}}$ & $0.54 \pm 0.05^{\mathrm{a}}$ \\
$60 \mathrm{mg} / \mathrm{kg} \mathrm{STZ}$ & $3.61 \pm 0.17^{\mathrm{a}}$ & $0.90 \pm 0.05^{*}$ & $0.38 \pm 0.04$ \\
$60 \mathrm{mg} / \mathrm{kg} \mathrm{STZ}+$ METFORMIN & $4.51 \pm 0.29^{\mathrm{b}^{*}}$ & $0.93 \pm 0.03^{*}$ & $0.30 \pm 0.06^{*}$ \\
$60 \mathrm{mg} / \mathrm{kg} \mathrm{STZ}+$ H.U. (800 mg) & $4.76 \pm 0.06^{\mathrm{b}^{*}}$ & $0.83 \pm 0.04$ & $0.44 \pm 0.06$ \\
$60 \mathrm{mg} / \mathrm{kg} \mathrm{STZ}+$ H.U. $(400 \mathrm{mg})$ & $4.65 \pm 0.12^{\mathrm{b}^{*}}$ & $0.84 \pm 0.03$ & $0.47 \pm 0.86$ \\
\hline
\end{tabular}

Superscripts ${ }^{*} \mathrm{a} b$ represent values that are significantly $(p<0.05)$ different from negative control, metformin treated group and positive control respectively
H. umbellata diminished blood glucose levels in both normal and STZ-initiated diabetic rodents. In this manner, the concentrate upgraded glucose use and improves resistance in glucose loaded rodents.

Diabetes induces oxidative stress through the overproduction of reactive oxygen species [27]. Antioxidants combat or counter the effect of oxidative stress by neutralizing these reactive oxygen species. Peroxidase is an inducible catalyst which expressed uniquely under conditions that permit its gene expression. It catalyzes a response of the structure: ROOR' + electron donor (2 e $-)+2 \mathrm{H}+\rightarrow \mathrm{ROH}+\mathrm{R}^{\prime} \mathrm{OH}$. The ideal substrate is hydrogen peroxide, and it is initiated by the presence of hydrogen peroxide. An increase in the activities of peroxidase in the liver and kidney of $H$. umbellata-treated rats indicates increased levels of hydrogen peroxide, and its activity could be linked to efficient hydrogen peroxide scavenging power of $H$. umbellata. An increase in the activity of GST in kidneys of $H$. umbellata-treated rats compared to the untreated diabetic rats, demonstrates the ability of the seed extract to combat free radicals. These increases in H. umbellata- treated rats are comparable to that of metformin-treated rats, this suggests that metformin has a greater ability to combat free radicals.

Lipid peroxides are the secondary products of oxidative stress and develop because of ROS generated during lipid peroxidation in diabetes. Raised amounts of lipid peroxides in the liver tissue uncover a serious level of lipid peroxidation which is viewed as a pointer of hepatocyte damage. They may likewise respond with transition metals like iron or copper to frame stable aldehydes, for example, malondialdehyde (MDA), that harm cell membranes [28]. An increase in lipid peroxidation suggests a decline in defence mechanisms of enzymatic and non-enzymatic antioxidants. The reduction in the thiobarbituric acid reactive substances (TBARS) concentrations in the kidneys and liver of rats treated with $H$. umbellata suggests an increase in the activity of antioxidant enzymes [29]. Additionally, the presence of alkaloids and flavonoids in $H$. umbellata could represent its defensive consequences for the liver and kidney, since these phytochemicals have been accounted for to give insurance on the kidneys and liver through avoidance of tissue lipid peroxidation which clarifies their cell reinforcement and free radical scavenging activities [30, 31].

GSH is a significant non-protein thiol in living creatures that assumes a focal role in planning the body's cell antioxidant guard measure [32]. It is associated with cell protection against xenobiotic and normally reactive species. A few reports acclaim that the GSH framework can be overpowered if ROS are generated in overabundance. In Table 7, high convergence of GSH and were seen in the kidney in $H$. umbellata-treated rodents in 
examination with the untreated diabetic rodents. This demonstrates that the plant has free radical scavenging capability.

\section{Conclusions}

Overall, based on the above results, the antidiabetic activity of $H$. umbellata at $800 \mathrm{mg} / \mathrm{kg}$ is comparable to that of metformin and the increase in the activity of GST, GSH and peroxidase shows that the seed extract of $H$. umbellata owing to its strong antioxidant potential can reduce the oxidative stress generated in diabetes, thereby protecting against diabetes-induced oxidative damage.

Therefore, it can be concluded that H. umbellata protects against streptozotocin-induced diabetes via regulation of blood glucose, inhibition of oxidative stress and enhancement of antioxidant enzymes in the liver, spleen and kidney.

Institutional Review Board Statement The study was conducted according to the guidelines of the Declaration of Helsinki, and approved by the Institutional Review Board of Covenant University, Ota Ogun State.

\section{Acknowledgements}

Not applicable.

\section{Authors' contributions}

Olubanke Olujoke Ogunlana., conceptualization, methodology, resources investigation writing original draft, review and editing; Babatunde Oluwafemi Adetuyi., investigation, resources, writing original draft; Miracle Ibukun Rotimi., lohor Esalomi., Alaba Adeyemi., Julie Akinyele., methodology investigation, writing original draft; Oluseyi E. Ogunlana., data curation, resources, methodology, writing original draft, review and editing; Oluwatosin A. Adetuyi., Oluwaseun A. Adebisi., Edward K. Opata., Roua S. Baty and Gaber El-Saber Batiha., resources, writing original draft. All authors have read and agreed to the published version of the manuscript.

\section{Funding}

This research did not receive any specific grant from funding agencies in the public, commercial, or not-for-profit sectors.

\section{Availability of data and materials}

The data sets used and/or analyzed during the current study are available from the corresponding author on reasonable request. All data generated or analyzed during this study are included in this published article.

\section{Declarations}

Ethics approval and consent to participate

Not applicable.

\section{Competing interest}

The authors have no conflicts of interest to declare regarding the publication of this paper.

\section{Author details}

'Department of Biological Sciences (Biochemistry Unit, Covenant University, Ogun State, Ota, Nigeria. ${ }^{2}$ Department of Natural Sciences (Biochemistry unit), Faculty of Pure and Applied Sciences, Precious Cornerstone University, Ibadan, Oyo State, Nigeria. ${ }^{3}$ Department of Biochemistry, Osun State University, P.M.B 4494 Osogbo, Nigeria. ${ }^{4}$ Department of Biotechnology, College of Science, Taif University, P.O. Box 11099, 21944 Taif, Saudi Arabia.
${ }^{5}$ Department of Pharmacology and Therapeutics, Faculty of Veterinary Medicines, Damanhour University, 22511 Damanhour, Egypt.

Received: 5 February 2021 Accepted: 1 June 2021

Published online: 15 June 2021

References

1. Chinenye S, Young E. State of Diabetes Care In Nigeria: A Review. Niger Heal J. 2011;11:101-6.

2. World Health Organization. Diabetes mellitus. Second report, Technical report series. Geneva; 1985

3. Selby NM, Taal MW. An updated overview of diabetic nephropathy: Diagnosis, prognosis, treatment goals and latest guidelines. Diabetes Obes Metab. 2020;22:3-15

4. Yang H, Sloan G, Ye Y, Wang S, Duan B, Tesfaye S, et al. New Perspective in Diabetic Neuropathy: From the Periphery to the Brain, a Call for Early Detection, and Precision Medicine. Front Endocrinol (Lausanne). 2020;10:1-13.

5. Hendrick AM, Gibson MV, Kulshreshtha A. Diabetic Retinopathy. Prim Care Clin Off Pract. 2015:42:451-64.

6. Eledrisi M, Elzouki A-N. Management of diabetic ketoacidosis in adults: A narrative review. Saudi J Med Med Sci. 2020;8:165.

7. Mohamed J, Nazratun Nafizah AH, Zariyantey AH, Budin SB. Mechanisms of diabetes-induced liver damage: The role of oxidative stress and inflammation. Sultan Qaboos Univ Med J. 2016;16:e132-41.

8. El Gawly HW, Tawfik MK, Rashwan MF, Baruzaig AS. The effect of pioglitazone on the liver of streptozotocin-induced diabetic albino wistar rats. Eur Rev Med Pharmacol Sci. 2009:13:443-51.

9. Godinho I, Gameiro J, Jorge S, Abreu F, Neves M, Lopes JA, et al. Diabetes, deafness and renal disease. Clin Kidney J. 2017;10:487-9.

10. Ebaid H, Al-Tamimi J, Metwalli A, Allam A, Zohir K, Ajarem J, et al. Effect of STZ-induced diabetes on spleen of rats: Improvement by camel whey proteins. Pak J Zool. 2015:47:1109-16.

11. Farnworth N. Ethnopharmacology and drug development. Chichester: John Wiley Books and Sons; 1994.

12. Sofowora EA. Medicinal Plants and Traditional Medicine in African. 2nd ed. Ibadan: John Wiley Books and Sons; 1993.

13. Adeneye AA, Adeyemi OO. Hypoglycaemic effects of the aqueous seed extract of Hunteria umbellata in normoglycaemic and glucoseand nicotineinduced hyperglycaemic rats. Int J Appl Res Nat Prod. 2009;2:9-18.

14. Igbe I, Omogbai EKI, Ozolua RI. Hypoglycemic activity of aqueous seed extract of Hunteria umbellata in normal and streptozotocin-induced diabetic rats. Pharm Biol. 2009;47:1011-6.

15. Momodu O, Enogieru A, Omoruyi S, Om`Iniabohs FAE. Extracts of Hunteria umbellata reverses the effect of streptozotocin-induced pancreatic islet-cell destruction. J Exp Clin Anat. 2014;13:66

16. Oboh G, Adebayo AA, Ademosun AO. Erection-stimulating, anti-diabetic and antioxidant properties of Hunteria umbellata and Cylicodiscus gabunensis water extractable phytochemicals. J Complement Integr Med. 2018;15:1-12.

17. Oboh G, Adebayo AA, Ademosun AO, Abegunde OA. Aphrodisiac effect of Hunteria umbellata seed extract: Modulation of nitric oxide level and arginase activity in vivo. Pathophysiology. 2019;26:39-47.

18. Adeneye AA, Crooks PA. Weight losing, antihyperlipidemic and cardioprotective effects of the alkaloid fraction of Hunteria umbellata seed extract on normal and triton-induced hyperlipidemic rats. Asian Pac J Trop Biomed. 2015:5:387-94.

19. Sedlak J, Lindsay RH. Estimation of total, protein-bound, and nonprotein sulfhydryl groups in tissue with Ellman's reagent. Anal Biochem. 1968;25: 192-205.

20. Habig WH, Pabst MJ, Jakoby WB. Glutathione $S$ transferases. The first enzymatic step in mercapturic acid formation. J Biol Chem. 1974;249: 7130-9.

21. Usoh IF, Akpan EJ, Etim EO, Farombi EO. Antioxidant Actions of Dried Flower Extracts of Hibiscus sabdariffa L. On Sodium Arsenite - Induced Oxidative Stress in Rats. Pakistan J Nutr. 2005:4:135-41.

22. Buege JA, Aust SD. Microsomal Lipid Peroxidation. Methods Enzymol. 1978; 52:302-10.

23. Reddy KP, Subhani SM, Khan PA, Kumar K. Effect of light and benzyl adenine and dark- treated graving rice (Oryza sativa) leaves -changes in peroxidases activity. Plant Cell Physiol. 1995;26:220-28. 
24. Momoh AOL. J. Effects of Methanolic seed extract of Hunteria umbellata (abere) on blood glucose level, hematological and lipid profile parameters in alloxan- induced diabetes in male rats. Pinnacle Med Medicial Sci. 2014; 34:225-30.

25. Genet S, Kale RK, Baquer NZ. Effects of vanadate, insulin and fenugreek (Trigonella foenum graecum) on creatine kinase levels in tissues of diabetic rat. Indian J Exp Biol. 1999;37:200-2.

26. Ahn CY, Bae SK, Jung YS, Lee I, Kim YC, Lee MG, et al. Pharmacokinetic parameters of chlorzoxazone and its main metabolite, 6hydroxychlorzoxazone, after intravenous and oral administration of chlorzoxazone to liver cirrhotic rats with diabetes mellitus. Drug Metab Dispos. 2008;36:1233-41.

27. Shruti S, Singh P, Mishra G, Jha KK, Khosa RL. Costus speciosus (Keukand): a review. Der Pharm Sin. 2011;2:28-34.

28. Halliwell B, Chirico S, Crawford MA, Bjerve KS, Gey KF. Lipid peroxidation: Its mechanism, measurement, and significance. Am J Clin Nutr. 1993;57:156-64.

29. Indradevi S, Ilavenil S, Kaleeswaran B, Srigopalram S, Ravikumar S. Ethanolic extract of Crinum asiaticum attenuates hyperglycemia-mediated oxidative stress and protects hepatocytes in alloxan induced experimental diabetic rats. J King Saud Univ - Sci. 2012;24:171-7.

30. Fraga CG, Martino VS, Ferraro GE, Coussio JD, Boveris A. Flavonoids as antioxidants evaluated by in vitro and in situ liver chemiluminescence. Biochem Pharmacol. 1987;36:717-20.

31. Sanz MJ, Ferrandiz ML, Cejudo M, Terencio MC, Gil B, Bustos G, et al. Influence of a series of natural flavonoids on free radical generating systems and oxidative stress. Xenobiotica. 1994;24:689-99.

32. Adetuyi BO, Okeowo TO, Adetuyi OA, Adebisi OA, Ogunlana OO, Oretade OJ, et al. Ganoderma lucidum from red mushroom attenuates formaldehyde-induced liver damage in experimental male rat model. Biology (Basel). 2020;9:1-11.

\section{Publisher's Note}

Springer Nature remains neutral with regard to jurisdictional claims in published maps and institutional affiliations.

\section{Submit your manuscript to a SpringerOpen ${ }^{\circ}$ journal and benefit from:}

- Convenient online submission

- Rigorous peer review

- Open access: articles freely available online

- High visibility within the field

- Retaining the copyright to your article

Submit your next manuscript at $\boldsymbol{\nabla}$ springeropen.com 